somewhat deflected face, and the crown of the fourth premolar about twice the length of its 'pillar'; (4) a type characterized by short broad metacarpals, a short face, broad and flat between the orbits, and nearly in a line with the cranium, and by the crown of the fourth premolar being twice the length of its 'pillar'; and (5) a type with short wide metacarpals, the face long and strongly deflected, and the crown of the fourth premolar about 1.5 times the length of its 'pillar'. Only the varieties characterized by molars with short 'pillar's' are dealt with in this communication. The possible ancestors of the short-pillared varieties are Equus sivalensis of Indian Pliocene deposits, $E$. stenonis of the Pliocene deposits of Europe and North Africa, and a new species, $E$. gracilis.

Arabs, barbs, thoroughbreds, and other modern breeds with a long deflected face, broad and prominent between the orbits, and the limbs slender, seem to have mainly sprung from $E$. sivalensis, while certain unimprored breeds, with a deflected face but very short 'pillars', are probably related to $E$. stenonis. Exmoor, Hebridean, Iceland, and other ponies of the 'Celtic' type, as well as ponies found in the South of France, the West Indies, and Mexico, characterized by a fine narrow skull, slender limbs, and the absence of ergots and hind chestnuts, are regarded as the descendants of $E$. gracilis, which includes (1) the small species of the English drift described by Owen as a fossil ass or zebra (Asinus fossilis); (2) the small species of French Pliocene and Pleistocene deposits known to palæontologists as E. ligeris; and (3) the small species of North African Pleistocene deposits known as $E$. asinus atlanticus, and hitherto believed to be closely related to, if not the ancestor of, zebras of the Burchell type. By crossing experiments evidence has been obtained of the wide distribution of horses of the $E$. gracilis type; that broad-browed Arabs and thoroughbreds with the face nearly in a line with the cranium are mainly a blend of a southern variety of $E$. gracilis (E. caballus libycus) and a horse of the 'forest' or Solutrè type, and that heavy breeds have not inherited their coarse limbs from a species closely allied to the wild horse of Mongolia.

\title{
OORRESPONDENOE.
}

\section{VORTICOSE MOVEMENT IN THE EARTHQUAKE OF BENAVENTE, PORTUGAL.}

SrR,-On May 14 I visited the well-known convent of Batalha (6 miles south of Leiria) in Portugal. On ascending to the roof the caretaker drew my attention to the effect on the building of the earthquake of Benarente, which occurred at 5 p.m. on April 23, 1909. The roof (of stone) is adorned with numerous four-sided pyramidal Gothic pinnacles. In two of these, while the lower part of each pinnacle has retained its original place, the upper part has been displaced by the earthquake and partially rotated, so that the angle of the upper part, facing (say) north, is turned through part of 
a circle towards the west. Similar effects have often been recorded.' Fourteen (or more) of the slender stone finials, each crowning a separate pinnacle, were broken off by the shock. I cannot be sure of the exact number, as I only saw the freshly fractured bases of three finials from above. In several places on the roof stones were horizontally displaced by the earthquake, from 1 inch at one end of the stone to nothing at the other end.

B. Hobson.

\section{MISOEIIANEOUS.}

Royal Societr.-At the Conversazione held on June 24, 1909, the following specimens were exhibited:-Sections of Seasonal Clay from Stockholm.-This clay, which was deposited during the melting and retreat of the great ice-sheet in Sweden, may be described as fossil years and seasons. The alternating bands of dark and light are easily seen, and Baron G. de Geer (from whom the specimens have been received), believes that each cycle represents a year, the lighter rock having been formed during the melting of the snows in spring. $\mathrm{He}$ has traced these bands for great distances, and has been able to map the changing limits of the ice-sheet from year to year through a long period. This is the nearest approach to a definite chronology by years that has yet been made by geologists, but it still needs to be linked up to the chronology of human history. Exhibited by Dr. F. A. Bather, F.R.S.

Skull of Megalosaurus from the Great Oolite of Gloucestershire.This is the first nearly complete skull of a carnivorous Dinosaur found in Europe, and agrees with the skull of Ceratosaurus, from the Jurassic of Colorado, U.S.A., in exhibiting a bony horn-core on the nose. The specimen was discovered by Mr. F. L. Bradley, F.G.S., near Minchinhampton. Exhibited by Dr. A. Smith Woodward, F.R.S.

New Museua a' Louth, Lincolnshire.-The strenuous efforts of the late Mr. Samuel Cresswell, Mr. Benjamin Crow, Mr. Joseph Larder, Mr. R. W. Goulding, and the band of earnest workers in Louth, have at last been crowned with success in that the Pahud Trustees of that town have placed at the disposal of the Committee of the Louth Antiquarian and Naturalists' Society the handsome sum of $£ 250$ towards a proper building. The Committee consider that they will require at least double this sum for the purpose of building and equipping a Museum and meeting-room on a site in Enginegate, the property of the Corporation, and the plan of such a building is now under consideration. The excellent collection of local antiquarian and scientific specimens are at present housed in dangerous and crowded quarters, and any contributor to the fund may be assured that he is helping forward a movement of great value to the town and district. Cheques may be drawn in favour of $\mathrm{Mr}$. B. Crow, the Hon. Treasurer, The Museum, New Street, Louth, Lincs.

1 Convent of S. Bruno, Stefano del Bosco, Calabria, in 1783 ; Lyell, Principles of Geology, 12 th ed., 1875, ii, p. 119; Tokio, 1880; F. Fouqué, Les Tremblements de Terre, 1889, p. 56; Beltuno, 1873; Aix la Chapelle, 1878; W. H. Hobbs, Earthquakes, 1908, p. 92. 